\title{
LEGAL RESTRICTIONS: THE NATURE AND FEATURES OF LEGAL CONFIRMATION AT THE INTERNATIONAL LEVEL
}

Galina S. Belyaeva ${ }^{1}$, Victoria V. Kutko ${ }^{2}$, Vera P. Kutina ${ }^{3}$, Vladislav Yu. Turanin ${ }^{4}$, Neonila A. Turanina ${ }^{5}$

${ }^{1,2,4}$ Belgorod State University, 85 Pobedy St., Belgorod, 308015, Russia, ${ }^{3}$ St. Petersburg state budgetary professional educational institution "Academy of mechanical engineering named after Zhozef Yakovlevich Kotin", Russia,

${ }^{5}$ Belgorod State Institute of Arts and Culture, 7 Koroleva St., Belgorod, 308033, Russia.

Email: ${ }^{1}$ asia@ prescopus.com, ${ }^{2}$ michael.1@ prescopus.com, ${ }^{3}$ kutiny@mail.ru, ${ }^{4}$ peter.seliverstov@ prescopus.com, ${ }^{5}$ belvp46@mail.ru Article History: Received on $25^{\text {th }}$ July 2019, Revised on $01^{\text {st }}$ September 2019, Published on $12^{\text {th }}$ October 2019

\begin{abstract}
Purpose: In this article, some questions legal restrictions, their nature and features of legal confirmation on the international level were considered.
\end{abstract}

Methodology: The main international acts confirming the general conditions, ways, purposes, tasks and the legal restrictions establishment bases were analyzed.

Result: The role of international legal norms as the main reference points for restriction confirmation in the national legislation was defined. Following the results of the conducted research, the conclusion was drawn on the role of the law as the main form of restriction confirmation in the public sphere.

Applications: This research can be used for the universities, teachers and education students.

Novelty/Originality: In this research, the model of legal restrictions: the nature and features of legal confirmation at the international level are presented in a comprehensive and complete manner.

Keywords: restriction, legal restrictions, international legal acts, purposes of legal restrictions, ways, bases.

\section{INTRODUCTION}

Formation of civil society and creation of the constitutional state in modern conditions is closely interconnected with the subjective rights and freedoms, as well as with legal restrictions, both governmental and individual.

A little unilateral interest for the ideas of inviolability of the rights and freedoms of the person and citizen with inevitability recently led to the fact that the rights of some society members were in conflict with the rights of others? As well as with the general, public interest. There was a problem of finding balance in the system of the rights, freedoms, duties, and restrictions of the rights, freedoms, legitimate interests and powers of legal entities for maintenance of stability in the country, providing existence conditions for each individual, forward development of society and the state. Due to the specified circumstances further development of the restrictions theory of the rights and freedoms of the person and citizen and the government becomes an objective necessity.

As E. A. Sedov fairly notes, "search of an optimum ratio between providing necessary freedom to each member of society and reasonable restrictions of this freedom for maintenance of public order was and remains one of the most difficult, social problems, delicate and relevant for all human communities" (ㅎuzjarova M.I. 2018; $\underline{\text { Ashmarov I.A. 2018). }}$

However in jurisprudence and law practice there is no uniform approach to general-theoretical interpretation of the legal restrictions institute in relation to various legal entities (individual and collective), this institute did not receive independent studying that cannot but have an adverse effect on the industry legislation designed to settle the considered relations concerning the established sphere of legal influence.

\section{METHODOLOGY}

The methodological basis of the current research is based on various general scientific methods and ways of scientific knowledge (analysis, synthesis, deduction, induction, system, and structural, formal and logical approaches) as well as particular scientific methods - legalistic, comparative and legal-and-interpretative.

\section{DISCUSSION AND RESULTS}

It should be noted that in the legal doctrine the problem of the concept, entities, and the content of legal restrictions is debatable owing to the complexity of the last.

Subjects of numerous researches are: the social-and-legal and political-and-legal restrictions in the sphere of realization of the government (management), essence and content of legal restrictions in a general-theoretical foreshortening, restrictions of the rights and freedoms of the person (person, citizen), concepts, the concept and the system of restriction of the government (Aminova D. K., \& Tsakhaeva, A. A. 2018). Restrictions are researched from various positions and points of view: requirements of a specific sort of the public relations and the corresponding legal levers; methods and ways of legal regulation; principles and functions of the law. 
In this accord, the problem is the situation with lack of the conceptual theory (the official doctrine) of legal restrictions: restrictions of the rights and freedoms of the person and citizen and the government, and the fact that the institute of legal restrictions remains unexplored in the proper degree demanded by legal reality. In particular, there is no uniform approach to general-theoretical interpretation of a concept of legal restrictions in relation to various legal entities (individual and collective) in jurisprudence and law practice and, as a result, inability of the industry legislation to govern the considered relations concerning the established sphere of legal influence.

The Russian legal system today, more than ever, needs a complex and system general-theoretical research of legal restrictions institute, its concepts, entities, contents, structure, and functions. In this regard the appeal to knowledge of the general regularities of confirming the legal restrictions on the international level is important.

The modern international standards integrated into the national legislation provide an opportunity to work in the legal system of the state with assistance of the national legislation, at the same time on behalf of the state a certain set of the measures directed to recognition of validity of the international legal norms and their realization inactivity of public authorities is accepted.

Among the most important international documents enshrining provisions of the institute of legal restrictions it is possible to name the Universal Declaration of Human Rights of 1948 (further in the text - the Declaration). The feature of its status lies in its advisory nature. However, currently its provisions in quality of the principles of international law are obligatory and are widely used as model in many countries of the world at the designing of provisions of the Constitution, laws, and documents concerning human rights.

Russia, in turn, unconditionally recognizes validity of this situation, and in Resolutions of the Constitutional Court of the Russian Federation after the instruction of various standards of the Constitution of the Russian Federation are corresponded by particular articles of the Universal Declaration of Human Rights and the European Convention on protection of human rights, a conclusion that the specified provisions as belonging to the conventional principles and rules of international law, according to article 15 (part 4) of the Constitution of the Russian Federation are a component of legal system of the Russian Federation stands.

The declaration for the first time in the history of mankind formulated the basic and general rights which have to be perceived according to the legislation and the fact that admissible restrictions extend to all declared rights (Art. 29 of the Declaration). This, very generalized from the point of view of the law, a formulation concerning restrictions allows to express fears of the following aspect: "consolidation of the general words conceals in itself dangerous and if not to abuse them, then, in any case, this statement is disproportionate protected in favor of restrictive measures" (Borisov V.I. 2018; Gadzaov A.F., Dzerzhinskaya M.R. 2018).

At the same time, in the subsequent documents this norm principle was significantly concretized (Von Glahn, G., \& Taulbee, J. L. (2015). ).

Thus, in the International Covenant on Civil and Political Rights of December 16, 1966, it is already said that "any restriction that the fundamental human rights recognized or participating in the present document by law, conventions, rules or customs, are not assumed under that pretext of such rights". Let's notice that in the Russian legislation similar provisions are contained in part 1 of article 55 of the Constitution of the Russian Federation (Koh, H. H. (1997))

In the context of the analysis of the international legal norms which are institute of legal restrictions the addressing contents of the Convention on protection of human rights and fundamental freedoms of 1950 it is important (further: The Convention, used as the main legal tool inactivity of the European Court of Human Rights (ECHR), in turn, being according to the charter, body of protection of the Convention.

The provisions of the Convention determining the content of legal restrictions on degree the formalizations, significantly differ from similar provisions of the Universal Declaration of Human Rights: first, the residual principle in formulation of restrictions of the rights is characteristic of the Convention, i.e. the right appears inviolable and its deprivation, except for the cases established by the Convention; secondly, this document rather accurately defines the bases of restriction of the rights and fundamental freedoms. So, it is enshrined in Art. 8 that any intervention by public authorities in the sphere of implementation of the right for respect of private and family life, the dwelling and correspondence of the citizen is inadmissible, except for cases when "such intervention is provided by the law and it is necessary for the interests of national security and public order, economic well-being of nation, for prevention of crime, disorders, protection of health and morality, protection of the rights and freedoms". This tendency is traced also in other articles of the Convention (article 9 of the Convention).

Summing up some result, we will notice that the analyzed international standards which are institute of legal restrictions state:

a) General conditions (purposes, forms, harmony, discrimination ban) restrictions of all rights and personal freedoms (Art. 2 and 29 of the Declaration, Art. 2 of the Covenant on Civil and Political Rights, Art. 14 of the Convention. The fullest list of such general conditions contains in the p. 2 of Art. 29 of the Declaration: "On implementation of the rights and freedoms each person has to be exposed only to such restrictions that are set by the law only for the purpose of ensuring 
due recognition and respect of the rights and freedoms of others and the satisfaction of fair requirements of morals, public order and the general welfare in democratic society");

b) The absolute rights and personal freedoms which are not subject to restrictions under no circumstances (for example, freedom from slavery and servitude (Art. 4 of the Declaration, Art. 8 of the Covenant on Civil and Political Rights, Art. 4 of the Convention); the right not to be exposed to tortures, brutal or degrading treatment or punishment (Art. 5 of the Declaration, Art. 7 of the Covenant on Civil and Political Rights, Art. 3 of the Convention);

c) Ways, cases, purposes of restriction of the separate rights and personal freedoms (Art. 9, 12, 14, 15, 17 of the Declaration, Art. 6, 8, 9, 10, 12, 13, 17, 18, 19, 20, 21, 22, 25 of the Covenant on Civil and Political Rights of 1966, Art. 2, 5, 8, 9, 10, 11 of the Convention. Concerning some rights and freedoms of the person and citizen, the main international acts formulate the bases (cases) of their restriction with an exhaustive image (the right for life, the right to physical freedom). Concerning others only the private purposes of restrictions of the rights and freedoms of the individual are established, and establishment of specific restrictions of these rights and freedoms is carried out by the state);

d) A possibility of restriction of the rights and freedoms of representatives of separate groups of the population (military personnel, police officers, priests, foreign citizens) (Art. 22 of the Covenant on Civil and Political Rights allows the introduction of special restrictions of the right for assemblies and the right for the introducing the persons which are a part of armed forces and police into them);

e) The principles of restriction of the rights and personal freedoms in the conditions of special state legal regimes (St. 4 Covenants on Civil and Political rights allow the states to depart from the obligations to the rights and freedoms of the person during the state of emergency: "1. During state of emergency in the state at which life of the nation is under the threat and about which existence officially appears the states participating in the present Pact can take measures in derogation from the obligations under the present Pact only in such degree in which it is required by sharpness of situation provided that such measures are not incompatible with their other obligations for international law and do not involve discrimination only on the basis of race, skin color, sex, language, religion or social origin. 2. This situation cannot form the basis for any derogations from articles 6, 7,8 (points 1 and 2), 11, 15, 16 and 18").

Rather detailed systematization of these provisions which are contained in international legal norms has for formation and realization of National Institute of legal restrictions basic value on the following circumstances:

- Have to be considered when developing the current federal legislation setting restrictions of the rights and freedoms of the person and the citizen (the p. 4 of Art. 15 and p.1 Art. 17 of the Constitution of the Russian Federation);

- Have to be taken into account by law enforcement, judicial and other law-enforcement agencies in the practical activities. So, for example, the international standards of restriction of the rights and freedoms of the person are used by the Constitutional Court of the Russian Federation at the permission of concrete affairs;

- Are additional guarantees of protection of the rights and freedoms of the person against any restrictions (Amerasinghe, C. F. (2005));

- Allow to reveal gaps and collisions in national legal regulation and to define the directions of improvement of legal restrictions institute in the specific state.

The question of the bases of legal restrictions is no less important. On one hand, legal restrictions are legal owing to the fact that is based on the right which can be recognized as the most important and most universal way of confirming public restrictions.

At the same time the rule of law, according to M. Horwitz as restriction of the government protects the citizen, but at the same time subjects the individual to the power of the heartless forms which replaced an arbitrariness, deprived of an opportunity to consider a human factor (sufferings, helplessness, etc.): "The rule of law creates formal equality - important advantage, but promotes inequality which forms such consciousness which considerably separates the law from policy, the purposes from means, processes from results" (Gadzhieva U.B. 2018; Gnatyuk S.N., Pekert N.A. 2018).

In this regard several words should be said about the approaches to legal restrictions based on convergence; first of all, concerning public subjects (the state and its bodies). They are developed by supporters of the discourse theory of the law which was created within the communicative theory of society by Y. Habermas, based on interrelation (interconditionality) of human rights and the idea of democracy, the idea of people's sovereignty (Kryuchkova K.S. 2018). According to this concept, the legitimacy does not come down to legal registration or ability of the power to effectively use violence resources, the laws embodying the main beginnings of the right are legitimate: social consent, public compromise, ideas of social justice.

Thus, the idea of restriction of the government with human rights best of all is entered in the western concept of human rights from the point of view of which human rights is a requirement to the state to make or refrain from commission of certain actions; means of guarding against abuse of public authorities (Kuznetsov A.A., Ignatyeva T.A., Kuznetsov A.O. 2018). Human rights are means of guarding against abuses of the power as from all the above-mentioned "internal" criteria 
of restriction of the government only they are a necessary "external" factor of control of its activity, a peculiar manifestation of the power of the personality, will of civil society.

\section{CONCLUSIONS}

Thus, legal restrictions are the limits of the resolved behavior of legal entities expressed in exceptions of certain opportunities in their activity and withdrawals from their legal status enshrined in the current legislation and provided with compulsory force, creating adverse conditions for satisfaction of own interests of subjects and directed to their control and at the same time to the interest satisfaction of the contractors or public interests protected by the state (Pauwelyn, J. $(2003))$.

Indisputable in conclusion of the problem analysis of this article highlighted in the heading is the fact that it is law (in its natural and legal and positive manifestations) as the official civilized, universal and most effective regulator of the public relations, the major social, cultural and moral value, a measure of freedom and responsibility of the personality has to be the main form of restriction confirmation, both the government, and the rights and freedoms of the person and citizen.

\section{ACKNOWLEDGMENTS}

The research is performed within a grant for support of the public and humanitarian directions of development of the Belgorod State National Research University on a subject "The state creating: mechanism of legal support of national security and direction of its improvement", order No. 540 ODES of 15.06.2018.

\section{REFERENCES}

1. Abuzjarova M.I. (2018). Tendencies, law of development and economic content of innovative entrepreneurship. Modern Economy Success. Issue. 1. P. 43-50.

2. Ashmarov I.A. (2018). Some approaches to the study of the USSR' military economy in the soviet and Russian national historiography. Historical Bulletin. Vol. 1. Issue 2. P. $19-31$.

3. Aminova D. K., \& Tsakhaeva, A. A. (2018). Effective preparation of the future psychologist as one of the elements of the security education system. International Journal of Medicine and Psychology. Vol. 1. Issue 3. P. $40-47$.

4. Borisov V.I. (2018). Influence of the food crisis for the revolution of the working mass of russia in the years of the first world war (August 1914 - February 1917). Historical Bulletin. Vol. 1. Issue 2. P. 49 - 55.

5. Gadzaov A.F., Dzerzhinskaya M.R. (2018). Mathematical methods of analysis of the periodic components of economic processes. Modern Economy Success. Issue 1. P. 14 - 18.

6. Gadzhieva U.B. (2018). Socialization of personality as a factor in the mental, intellectual and spiritual-moral development. International Journal of Medicine and Psychology. Vol. 1. Issue 2. P. 17 - 20.

7. Gnatyuk S.N., Pekert N.A. (2018). Education as a factor of sustainable development of agriculture. Russian Economic Bulletin. Vol. 1. Issue 3. P. $18-27$.

8. Kryuchkova K.S. (2018) Modular training of future teachers with the use of information technologies in the conditions of virtual academic mobility. Modern Humanities Success. Issue 4. P. 9 - 14.

9. Kuznetsov A.A., Ignatyeva T.A., Kuznetsov A.O. (2018). Strategy and key elements of competitiveness. Modern Economy Success. Issue 1. P. $25-29$.

10. Von Glahn, G., \& Taulbee, J. L. (2015). Law among nations: an introduction to public international law. Routledge. https://doi.org/10.4324/9781315663708

11. Koh, H. H. (1997). Why do nations obey international law? https://doi.org/10.2307/797228

12. Amerasinghe, C. F. (2005). Principles of the institutional law of international organizations. Cambridge University Press. https://doi.org/10.1017/CBO9780511614224

13. Pauwelyn, J. (2003). Conflict of norms in public international law: how WTO law relates to other rules of international law (Vol. 29). cambridge university press. https://doi.org/10.1017/CBO9780511494550

14. Rosenberg, R. E., Law, J. K., Yenokyan, G., McGready, J., Kaufmann, W. E., \& Law, P. A. (2009). Characteristics and concordance of autism spectrum disorders among 277 twin pairs. Archives of pediatrics \& adolescent medicine, 163(10), 907-914. https://doi.org/10.1001/archpediatrics.2009.98

15. Lamy, P. (2006). The Place of the WTO and its Law in the International Legal Order. The European Journal of International Law, 17(5), 969-984. https://doi.org/10.1093/ejil/chl035

16. Kobersy, I. S., Karyagina, A. V., Karyagina, O. V., \& Shkurkin, D. (2015). Law as a social regulator of advertisement and advertising activity in the modern Russian information space. Mediterranean Journal of Social Sciences, 6(3 S4), 9. https://doi.org/10.5901/mjss.2015.v6n3s4p9

17. Simpson, G. (2004). Great powers and outlaw states: unequal sovereigns in the international legal order (Vol. 32). Cambridge University Press. https://doi.org/10.1017/CBO9780511494185

18. Steiner, H. J., Alston, P., \& Goodman, R. (2008). International human rights in context: law, politics, morals: text and materials. Oxford University Press, USA.

19. Cassese, A. (2013). Cassese's international criminal law. Oxford university press. https://doi.org/10.1093/he/9780199694921.001.0001 